\title{
Peranan Pembelajaran Pendidikan Kewarganegaraan Dalam Menanamkan Sikap Nasionalisme Pada Siswa di SMP Darul Hikmah Mataram
}

\author{
Abrar', Koamng Sundara ${ }^{2}$ \\ ${ }^{1}$ Pendidikan Pancasila dan Kewarganegaraan, Universitas Muhammadiyah Mataram, Email: abrar12@gmail.com \\ ${ }^{2}$ Pendidikan Pancasila dan Kewarganegaraan, Universitas Muhammadiyah Mataram, Email: komangsundara23@gmail.com
}

INFO ARTIKEL
Riwayat Artikel:
Diterima: 15-Juli-
2017
Disetujui: 25-
September-2017

\section{Kata Kunci:}

peranan

pendidikan

kewarganegaraan

menanamkan

sikap

nasionalisme

\begin{abstract}
ABSTRAK
Abstrak: Salah satu upaya pemerintah dalam menumbuhkan nasionalisme adalah dengan memberikan pemahaman melalui pembelajaran Pendidikan Kewarganegaraan mulai dari tingkat sekolah dasar sampai sekolah menengah atas, bahkan sampai ke perguruan tinggi. Tujuan penelitian ini adalah untuk mengetahui peranan pembelajaran Pendidikan Kewarganegaraan dalam menanamkan sikap nasionalisme pada siswa Sekolah Menengah Pertama Darul Hikmah Mataram. Metode dan pendekatan penelitian yang digunakan adalah deskriptif kualitatif. Metode pengumpulan data menggunakan observasi, wawancara dan dokumentasi. Jenis data berupa data kualitatif, dengan perolehan data sebagai sumber data primer melalui wawancara dan sumber data, dan data sekunder melalui dokumentasi serta catatan yang terkait. Analisis data menggunakan reduksi data, penyajian data, dan penarikan kesimpulan dan verifikasi. Hasil penelitian menunjukkan bahwa pembelajaran PKn yang dilaksanakan di SMP Darul Hikmah Mataram mampu menumbuhkan semangat nasionalisme para peserta didik. Hal ini terlihat dari kehidupan para siswa yang selalu antusias melaksanakan hari-hari besar nasional, melaksanakan upacara bendera, selalu aktif dalam kegiatan pramuka, rajin masuk sekolah, disiplin dalam kehidupan sehari-hari, rajin melaksanakan tugas yang diberikan guru. Kesadaran siswa-siswi akan pentingnya pendidikan sangat tinggi, terlihat pada saat proses belajar mengajar, jarang ada yang malas apalagi bolos. Jika ada siswa-siswi yang malas, biasanya setelah diberikan teguran dan nasihat akan sadar dengan sendirinya.
\end{abstract}

\begin{abstract}
One of the Government's efforts in fostering nationalism is to provide understanding through learning of citizenship education ranging from primary level to secondary school, even to the College. The purpose of this research is to know the role of civic education in cultivating a learning attitude of nationalism on a junior high school student Darul Hikmah Mataram. Research methods and approaches used is descriptive qualitative. Data collection method using observation, interview and documentation. The type of data in the form of qualitative data, with the acquisition of the data as the source of primary data through interviews and data sources, and secondary data through documentation and the related notes. Data analysis using data reduction, the presentation of data, and the verification conclusion and withdrawal. The results showed that the learning of PKn in SMP Darul Hikmah Mataram was able to foster a spirit of nationalism learners. This is apparent from the lives of the students who have always been enthusiastic about carrying out major national days, carry out ceremonial flags, always active in Boy Scout activities, diligently attend school, discipline in our daily lives, diligently perform the duties given the teacher. Awareness of the students of the importance of education is very high, visible at the time the process of teaching and learning, there are lazy much less skipping. If there are students who are lazy, usually after being given a reprimand and advice will be aware of its own.
\end{abstract}

\section{A. LATAR BELAKANG}

Pendidikan merupakan suatu usaha manusia untuk membina kepribadiannya sesuai dengan nilai-nilai yang ada di dalam masyarakat dan kebudayaan yang dimilikinya. Pendidikan sebagai salah satu cara untuk membina sikap dan mental generasi muda untuk semakin maju dalam mengisi kemerdekaan bangsa. Menurut Driyarkara pendidikan adalah memanusiakan manusia muda[1]. Sedangkan Pendidikan menurut Crow adalah tidak hanya dipandang sebagai sarana untuk mempersiapkan hidup yang akan datang, tetapi juga untuk kehidupan sekarang yang dialami individu dalam perkembangnnya menuju ketingkat kedewasaannya [1]. Sehingga dapat disimpulkan bahwa Pendidikan adalah segala usaha yang dilakukan untuk mendidik manusia sehingga dapat tumbuh dan berkembang serta memiliki potensi atau kemampuan sebagaimana mestinya [2]. 
Pendidikan nasional juga harus mampu menumbuhkembangkan rasa cinta tanah air (Nasionalisme) dengan demikian diharapkan akan lahir generasi penerus yang berkwalitas, memiliki keperibadian tinggi dan memiliki kemampuan dan keberanian dalammembangun bangsa dan negara, agar dapat memenuhi tujuan pendidikan yaitu membentuk manusia yang berkepribadian, melalui latihan otak, menambah benih kemerdekaan, dan keberanian yang luhur, berbuat baik dan membiasakan hidup sederhana.

Kemerdekaan Indonesia diperoleh dengan perjuangan yang penuh dengan pengorbanan, berupa darah, air mata, harta benda dan bahkan nyawa para pahlawan. Maka sepatutnyalah rasa Nasionalisme dan semangat perjuangan perlu dipelihara dan dipupuk terutama pada peserta didik, ditangan merekalah terletak masa depan bangsa yang akan datang, jika generasi bangsa ini baik dan bermoral tinggi, maka masa depan bangsa tentunya akan baik, dan sebaliknya jika generasi muda rusak dan bermoral rendah maka sudah pasti masa depan bangsa akan suram dan hancur. Oleh sebab itu semangat dan sikap Nasionalisme perlu ditanamkan dan dipelihara dalam jiwa peserta didik.

Berhubungan dengan sikap nasionalisme yang menurun, menurut hasil penelitian sebelimnya menunjukkan bawah nilai kebudayaan yang menjadi karakteristik bangsa Indonesia, seperti gotong royong, silahturahmi, ramah tamah dalam masyarakat menjadi keistimewaan dasar yang dapat menjadikan individuindividu masyarakat Indonesia untuk mencintai dan melestarikan kebudayaan bangsa sendiri. Tapi karakteristik masyarakat Indonesia yang dikenal sebagai masyarakat yang ramah dan sopan santun kini mulai pudar sejak masuknya budaya asing ke Indonesia yang tidak bisa diseleksi dengan baik oleh masyarakat Indonesia[3].

Cukup tinggi, baik dalam ketepatan waktu pembelajaran, pemberian sanksi-sanksi tegas dalam menindak siswa yang melakukan pelanggaran, pewajiban mengikuti kegiatan ekstrakurikuler, dan lain sebagainya[4]. Keragaman politik identitas suku, ras, antar golongan serta agama yang ada di Indonesia menuntut kita untuk hidup bertoleransi dan memiliki rasa solidaritas kebangsaan yang tinggi[5]. Budaya masyarakat juga akan mempengaruhi pada sikap nasionalisme pada bangsa[6].

Nasionalisme bangsa Indonesia pada masa sekarang sudah mengalami degradasi yang begitu hebat hal ini dapat dilihat dengan semakin menipisnya semangat persatuan dan kesatuan. Kerusuhan terjadi dimana-mana, banyak daerah yang ingin merdeka dan memisahkan diri dari Negara kesatuan Republik Indonesia seperti yang terjadi di beberapa daerah (Aceh, Maluku, Irian Jaya) semua itu terjadi disebabkan tipisnya nilai persatuan dan kesatuan serta lunturnya semangat Nasionalisme rakyat Indonesia dalam mempertahankan kemerdekaan yang telah diraih oleh para pahlawan dengan cucuran darah dan airmata.

Nasionalisme merupakan sikap yang harus tertanam dalam setiap individu. Sebagaimana hasil penelitian [7] dengan judul Peranan Pembelajaran Pendidikan Kewarganegaraan dalam Menanamkan Sikap Nasionalisme Siswa di Era Globalisasi. Hasil penelitiannya menunjukkan bahwa pembelajaran Pendidikan Kewarganegaraan (PKn) mempunyai peran penting dalam penanaman sikap nasio-nalisme siswa di era golobalisasi. Hal ini dibukatikan dengan materi pembelajaran PKn khususnya yang mengarah pada pembentukan sikap nasionalisme siswa. Selain itu juga dengan penggunaan sumber belajar, metode dan media pembelajaran yang bervariatif, dan sarana parasarana yang mendukung di dalam kelas serta dengan kegiatankegiatan yang diadakan oleh pihak sekolah maka sangat membantu guru dalam penanaman sikap nasionalisme.

Menyadari hal-hal yang terjadi di atas, maka semangat nasionalisme itu perlu ditanamkan dan dipelihara sejak dini terutama melalui kegiatan pembelajaran di sekolah khususnya di Sekolah Menengan Pertama (SMP) Darul Hikmah Mataram. Karena pada masa sekarang ini siswamasih banyak yang bersikap tidak mencerminkan sikap nasionalisme dalam kehidupan sehari-hari seperti yang tercermin dalam sikap gaya hidup, tindakan, gaya berpakaian, lagu-lagu yang dikuasai, bahasa bahkan sikap sehari-hari mereka lebih mencerminkan gaya hidup kebarat-baratan. Masih banyak siswa yang kurang disiplin dalam melaksa-nakan upacara bendera maupun dalam belajar, seperti masih banyak yang malas belajar dengan tidak masuk sekolah, sering bolos, bahkan masih banyak yang kurang peduli pada masalah yang dialami temannya, sehingga menyebabkan kurangnya rasa rela berkorban sebagaimana sikap para pahlawan.

Agar eksistensi budaya lokal tetap kukuh, maka kepada generasi penerus bangsa perlu ditanamkan rasa cinta terhadap budaya daerah. Salah satu cara yang dapat ditempuh guru di sekolah adalah dengan cara mengintegrasikan nilai-nilai kearifan lokal dalam proses pembelajaran di sekolah. Dengan mengintegrasikan nilai-nilai kearifan lokal ke dalam pembelajaran diharapkan nasionalisme siswa akan tetap kukuh terjaga di tengah-tengah derasnya arus globalisasi[8]. Dalam membinakan nilai-nilai Pancasila dan nasionalisme, PKn juga perlu menggunakan secara terintegrasi pendekatan pendidikan nilai secara langsung, yang didasari oleh perspektif sosialisasi, dan pendekatan pendidikan nilai secara tidak langsung, yang didasari oleh perspektif sosialisasi. Pembelajaran PKn pun hendaknya memiliki kekuatan (powerful), yakni pembelajaran PKn yang bermuatan nilai, bermakna, aktif, terpadu, mengundang kemampuan berfikir tingkat tinggi, demokratis, menyenangkan, efektif, efisien, kreatif, melalui belajar dengan bekerja sama (cooperative learning), dan mengundang aktivitas sosial[9]. 
Peran guru dalam meningkatkan sikap nasionalisme siswa dapat dilakukan dengan cara membimbing dan memberikan pesan-pesan moral pada siswa,memberikan nilai nasionalisme dengan menceritakan kisah-kisah para pahlawan dalam proses belajar mengajar, menggunakan metode yang bervariasi agar siswa tidak bosan dan cara tersebut dinilai efektif[10].

Jika semua ini dibiarkan begitu saja, maka dikhawatirkan akan muncul kemerosotan moral dan sikap pada siswa yang tidak sesuai dengan apa yang telah dicontohkan oleh para pahlawan. Jika sikap itu dibiarkan terus menerus maka sudah pasti semangat nasionalisme akan lenyap sama sekali. Inilah yang membuat peneliti tertarik untuk mengadakan penelitian dengan judul "Peranan Pembelajaran Pendidikan Kewarganegaraan (PKn) Dalam Menanamkan Sikap Nasionalisme Pada Siswa SMP Darul Hikmah Mataram. Adapun tujuan yang ingin dicapai dalam penelitian ini adalah untuk mengetahui peranan pembelajaran PKn dalam menanamkan sikap Nasionalisme pada siswa SMP Darul Hikmah Mataram.

\section{B. METODE PENELITIAN}

\section{Metode Penelitian yang Digunakan}

Jenis metode yang digunakan dalam penelitian ini adalah jenis penelitian kualitatif, sedangkan pendekatan yang digunakan adalah pendekatan deskriptif. Menurut [11] "jenis penelitian kualitatif adalah prosedur penelitian yang menghasilkan data-data deskriptif berupa kata-kata tertulisatau lisan dari orang-orang dan prilaku yang dapat diamati. Sehingga data yang dikumpulkan adalah data yang berupa kata/ kalimat maupun gambar (bukan angka-angka). Data-data ini bisa berupa naskah wawancara, catatan lapangan, foto, video, dokumen pribadi, memo ataupun dokumen resmi lainnya".

Kehadiran peneliti dalam penelitian ini adalah sebagai pengamat (peneliti) yang terjun langsung di lapangan, namun tanpa berperan serta yakni hanya melakukan satu fungsi sebagai pengamat. Adapun yang menjadi objek dalam penelitian ini adalah guru PKn dan siswa SMP Darul Hikmah. Kehadiran peneliti ketika berada di lapangan diketahui oleh subyek penelitian, karena sebelumnya peneliti menjelaskan status serta tujuan keberadaan peneliti di Sekolah. Hal itu sangat membantu peneliti dalam proses penggalian data dalam rangka menyelesaian skripsi yang sedang penulis lakukan.

\section{Subjek Penelitian}

Kehadiran peneliti dalam penelitian kualitatif sangat penting karena peneliti merupakan kunci utama dalam memperoleh data, peneliti sendiri atau dengan bantuan orang lain merupakan alat pengumpul data utama [11].
Jika memanfaatkan alat yang bukan manusia (bukan peneliti), maka alat itu tidak akan mungkin untuk mengadakan penyesuaian terhadap kenyataankenyataan yang ada di lapangan, karena itu hanya manusia atau peneliti lah yang dapat berhubungan dengan responden atau objek yang diamati dan hanya penelitilah yang mampu memahami tentang kenyataan yang ada dilapangan sehingga kehadirannya sebagai penentu yang sangat penting dalam memperoleh data.

Kehadiran peneliti dalam penelitian kualitatif cukup rumit, ia sekaligus sebagai perencana. Pelaksanaan pengumpulan data, analisis, penafsiran data, dan pada akhirnya ia menjadi pelopor hasil penelitian [11]. Selain itu juga dalam penelitian kualitatif, peneliti di anggap sebagai human instrument, berfungsi menetapkan fokus penelitian, memilih informan sebagai sumber data, menafsirkan data dan membuat kesimpulan atas temuannya [12].

Selanjutnya Nasution dalam [12] menjelaskan bahwa:

"Dalam penelitian kualitatif tidak ada pilihan lain dari pada menjadikan manusia sebagai instrument penelitian utama. Alasannya ialah bahwa segala sesuatunya belum mempunyai bentuk yang pasti. Dalam keadaan yang serba tidak pasti dan tidak jelas itu tidak ada pilihan lain dan hanya peneliti itu sendiri sebagai alat satu-satunya yang dapat mencapainya."

Dengan memahami penjelasan di atas maka kita dapat mengetahui bahwa peneliti sebagai kunci utama dalam penelitian, karena ia merupakan alat (instrument) yang akan menyimpulkan data-data yang ada di lapangan sesuai dengan apa yang diteliti.

\section{Jenis dan Sumber Data}

Jenis data yang digunakan adalah kualitatif. Sedangkan sumber data adalah segala sesuatu yang dapat memberikan informasi mengenai data. Berdasarkan sumbernya, data dibedakan menjadi dua, yaitu data primer dan data sekunder.

1. Data primer yaitu data yang dibuat oleh peneliti untuk maksud khusus menyelesaikan permasalahan yang sedang ditanganinya. Data dikumpulkan sendiri oleh peneliti langsung dari sumber pertama atau tempat objek penelitian dilakukan.

2. Data sekunder yaitu data yang telah dikumpulkan untuk maksud selain menyelesaikan masalah yang sedang dihadapi. Data ini dapat ditemukan dengan cepat. Dalam penelitian ini yang menjadi sumber data sekunder adalah literatur, artikel, jurnal serta situs di internet yang berkenaan dengan penelitian yang dilakukan [12].

Dalam penelitian ini data primer diperoleh dari wawancara dan observasi lansung oleh peneliti, sedangkan data sekunder didapatkan dari dokumentasi dan catatan lapangan. 


\section{Metode Pengumpulan Data}

Metode pengumpulan data merupakan langkah yang paling utama dalam penelitian, karena tujuan utama dalam penelitian adalah mendapatkan data. Tanpa mengetahui tekhnik pengumpulan data maka peneliti tidak akan mendapatkan data yang memenuhi standar data yang ditetapkan. Dalam penelitian ini peneliti menggunakan tiga metode pengumpulan data yaitu; mawancara, observasi, dan dokumentasi.

\section{a) Wawancara (interview)}

Wawancara adalah percakapan dengan maksud tertentu [11]. Percakapan itu dilakukan oleh dua pihak yaitu pewawancara (interview) yang mengajukan pertanyaan dan yang diwawancarai (interviewee) yang memberikan jawaban atas pertanyaan itu. Sedangkan menurut Esterbrg dalam [12] mendefinisikan interview (wawancara) sebagai pertemuan dua orang untuk bertukar informasi dan ide melalui Tanya jawab sehingga dapat dikonstruksikan makna dalam suatu topik tertntu, selanjutnya Esterberg juga menjelaskan bahwa wawancara merupakan hatinya penelitian sosial, karena sering dan harus digunakan dalam penelitianpenlitian sosial. Menurut Susan Stainback [12] melalui wawancara maka peneliti akan mengetahui hal-hal yang lebih mendalam tentang partisipan dalam menginterpretasikan situasi dan penemuan yang terjadi.

Dari pendapat-pendapat di atas dapat ditarik suatu kesimpulan bahwa metode wawancara adalah suatu metode dimana pewawancara dan yang diwawancara saling berinteraksi dalam rangka memperoleh informasi tentang data yang diteliti di lapangan.Kemudian bentuk wawancara yang peneliti pergunakan disini adalah wawancara bebas dan terpimpin dan dalam mengadakan wawancara peneliti hanya membaca pedoman yang berisi tentang hal-hal yang perlu ditanyakan.

\section{b) Observasi (Pengamatan)}

Pengamatan merupakan suatu think yang dilakukan oleh peneliti untuk memperoleh informasi di lapangan dengan cara langsung terjun melihat objek yang diteliti di lapangan, Hadi dalam [12] mengemukakan bahwa: observasi merupakan suatu proses yang kompleksi, suatu proses yang tersusun dari berbagai proses biologis dan psikologis. Dua diantara yang terpenting adalah proses-proses pengamatan dan ingatan. Adapun menurut [13] mengartikan bahwa obsrvasi disebut pula pengamatan yang meliputi kegiatan dan pemusatan perhatian terhadap suatu objek yang menggunakan seluruh indera.

Dari pendapat para ahli di atas dapat disimpulkan bahwa observasi merupakan suatu proses yang sangat kompleks yang membutuh-kan ingatan dalam rangka memperoleh inforrmasi di lapangan tentang apa yang di amati dan dilihatnya. Metode observasi di gunakan oleh peneliti dalam rangka memudah-kan peneliti untuk mendapatkan informasi dan gambaran mengenai objek yang diteliti yang terkait dengan judul yang peneliti angkat yaitu "peranan pembelajaran Pendidikan Kewargane-garaan dalam menanamkan sikap Nasionalisme pada siswa SMP Darul Hikmah Mataram.

\section{c) Dokumentasi}

Metode dokumentasi merupakan catatan peneliti yang sudah berlaku, yang bisa berbentuk lisan, gambar atau karya-karya monumental dari seseorang [12]. Sedangkan menurut Guba dan Lincoln dalam [11] mengartikan dokumen adalah setiap bahan tertulis ataupun film. Dokumen digunakan dalam penelitian karena sebagai sumber data karena dalam banyak hal dokumen sebagai sumber data dapat dimanfaatkan, untuk menguji, menafsirkan bahkan untuk meramalkan [11].

Metode dokumentasi digunakan dalam rangka untuk memperoleh informasi pendukung yang diperoleh dari sumber non manusia, seperti dokumen pribadi, dokumen resmi dan catatan-catatan lain yang sifatnya mendukung terhadap objek yang sedang diteliti di lapangan, sehingga nantinya peneliti betulbetul mem-peroleh informasi yang betul-betul bisa dipercaya.

\section{Teknik Analisi Data}

Bogdan dalam [12] menyatakan analisis data adalah proses mencari dan menyusun secara sistematis data yang diperoleh dari hasil wawancara, catatan lapangan dan bahan-bahan lain, sehingga dapat mudah dipahami dan semuanya dapat di informasikan kepada orang lain. Adapun menurut Susan Stainback dalam [14] mendefinisikan analisis data merupakan hal yang kritis dalam proses penelitian kualitatif. Karena analisis digunakan untuk memahami hubungan dan konsep dalam data sehingga hipotesis dapat dikembangkan dan di evaluasi.

1) Reduksi Data

Reduksi data diartikansebagai proses pemilihan, pemusatan perhatian pada penyederhanaan, pengabstrakan dan transformasi data kasar yang muncul dari catatan-catatan tertulis dilapangan. Reduksi data berlangsung terus-menerus selama penelitian dilakukan. Reduksi dilakukan dalam proses pengamatan dan wawancara. Reduksi data ini berlanjut terus selama penelitian dilapangan sampai laporan akhir lengkap tersusun.

Seperangkat hasil reduksi data juga perlu diorganisasikan kedalam suatu bentuk tertentu (display data) sehingga terlihat sosoknya secara utuh. Itu mirip semacam pembuatan tabel atau diagram dalam tradisi penelitian kualitatif. Ia bisa berbentuk sketsa, sinopsis, matriks, atau bentukbentuk lain. Itu sangat diperlukan untuk memudahkan upaya pemaparan dan penugasan kesimpulan (conclution drawing and verification).

2) Penyajian Data 
Merupakan sekumpulan informasi tersusun yang memberi kemungkinan adanya penarikan kesimpulan dan pengambilan tindakan. Beraneka penyajian kita temukan dalam keidupan sehari-hari seperti surat kabar,televisi, buku bacaan,dan lain sebagainya. Dengan melihat penyajian-penyajian kita dapat memahami apa yang sedang terjadi dan apa yang harus dilakukan berdasarkan atas pemahaman yang dapat dari penyajian-penyajian yang dikumpulkan oleh penulis selama melakukan penelitian, semuanya dirancang guna menggabungkan informasi yang tersusun. Dengan demikian seorang penganalisis dapat melihat apa yang sedang terjadi dan menentukan suatu kesimpulan.

3) Menarik kesimpulan atau verifikasi

Dari permulaan pengumpulan data, seorang penganalisis kualitatif mulai mencari arti bendabenda, pola-pola, penjelasan, konfigurasikonfigurasi yang mungkin, alur sebab akibat, dan proposisi. Penarikan kesimpulan hanyalah sebagian dari satu kegiatan dari konfigurasi selama yang utuh. Kesimpulan-kesimpulan juga diverifikasi selama penelitian belangsung. Verifikasi yang dilakukan penulis selama melakukan penelitian merupakan tinjauan ulang pada catatan-catatan lapangan dengan bertukar pikiran diantara teman sejawat untuk mengembangkan kesepakatan intersubjektif. Singkatnya, makna-makna yang muncul dari data harus diuji kebenarannya, kekokohannya, dan kecocokannya.

\section{HASIL DAN PEMBAHASAN}

\section{Sikap Nasionalisme Siswa}

Aspek-aspek nasionalisme merupakan unsurunsur yang terpenting pada sikap Nasionalisme itu sendiri. Aspek tersebut merupakan bagian yang tak terpisahkan dan merupakan inplementasi nyata dari Nasionalisme yang dimiliki oleh seorang individu. Unsur-unsur dari Nasionalisme yaitu kesetiaan tertinggi individu harus diserahkan kepada negara dan bangsanya, ikatan yang erat dengan tumpah darahnya, dengan tradisi dan penguasa di daerahnya. Aspekaspek nasionalisme yang harus dimiliki oleh siswaantara lain : setia pada Nusa Bangsa, sadar pada panggilan tugas, dan toleransi antara sesama.

Bagi siswa terutama yang berada di SMP Darul Hikmah Mataram yang peneliti jadikan sebagai obyek penelitian. Berdasarkan hasil wawancara dengan guru mata pelajaran PKn yaitu Bapak Mahpud, S.Pd mengatakan :

“..........di mana kesetiaan pada nusa dan bangsa dapat di wujudkan melalui perbuatan dan tingkah laku sehari-hari, baik di dalam lingkungan sekolah maupun di lingkungan masyarakat yang dapat diwujudkan dengan melakukan disiplin dalam sekolah, menyeimbangkan hak dan kewajiban, belajar dengan giat, ikut melakukan upacara bendera, toleransi terhadap sesama siswa dan mencintai kemajuan pembangunan. Hal-hal ini terlihat pada siswa yang melakukan kegiatan dengan disiplin contohnya tidak ada siswa yang terlambat masuk kelas atau mengikuti upacara bendera dll.." (wawancara, tanggal 22 November 2016).

Upacara bendera hari senin, yang merupakan salah satu upaya untuk tetap mempertahankan eksistensi nilai-nilai perjuangan bangsa yang telah memakan korban jutaan Rakyat Indonesia di masa lalu.Berdasarkan hasil observasi peneliti:

"Setiap siswa SMP Darul Hikmah Mataram dengan penuh rasa khidmat mengikuti pelaksanaannya, seolah-olah mereka ikut merasakan bagaimana perjuangan yang dilakukan oleh pendahulu bangsa ini" (wawancara, tanggal 22 November 2016).

Mengingat bahwa bangsa ini merupakan buah karya dari para pejuang yang dengan rela memperjuang dan mepertahankan kemerdekaan dengan seluruh jiwa dan raga mereka.Sehingga menjadi kewajiban setiap generasi penerus bangsa untuk menghargai dan ikut merasakan pahit getirnya perjuangan, meskipun hal itu ditunjukkan melalui pelaksanaan upaya bendera.

Sikap nasionalisme SMP Darul Hikmah Mataram juga ditunjukkan melalui interaksi dalam kehidupan sehari-hari di sekolah yaitu seperti penuturan salah satu wali kelas Maryanardi, S.Pd :

“.. salah satunya dengan membantu teman yang sedang mengalami sakit, di mana kalau ada salah seorang teman mereka yang sakit, maka mareka mengumpulkan iuran yang besaranya seikhlasnya, setelah terkumpul selanjutnya dikasi pada temannya yang sakit....." (wawancara, tanggal 22 November 2016).

\section{Peranan Pembelajaran PKn dalam Menanamkan Sikap Nasionalisme}

Pembelajaran PKn memiliki peranan yang penting dalam menanamkan dan menumbuhkan sikap nasionalisme pada peserta didik. Karena melalui PKn manusia di didik untuk menjadi manusia yang berfikir, mampu memikirkan apa yang telah terjadi. Kemudian direnungkan dan dijadikan sebagai pelajaran dan contoh dalam meniti kehidupan yang sekarang dan yang akan datang. Dengan PKn manusia bisa menjadi warga negara yang baik dan dengan PKn manusia bisa memilih mana perbuatan yang dianggap baik dan mana perbuatan yang buruk, mana perbuatan yang harus dilakukan dan mana perbuatan yang harus dijauhi. Untuk bisa memahami peristiwa sejarah dan masa kini yang telah terjadi tentunya harus melalui perenungan dan proses pemikiran", sehingga tepat bahwa: sesungguhnya pada kisah-kisah mereka itu terdapat pengajaran bagi orang-orang yang mempunyai akal (fikiran) (Ibu $\mathrm{Bq}$ Lina Marlina, S.PdWawancara: 16 Desember 2016). 
Melalui proses pembinaan terhadap generasi para siswa SMP Darul Hikmah Mataram ini sebagai penerus perjuangan bangsa. diharapkan mampu membentuk dirinya sebagai siswa yang bertanggung jawab, memiliki kepribadian luhur serta memiliki semangat nasionalisme yang tinggi baik ditengahtengah masyarakat maupun ditengah-tengah kehidupan bangsa dan Negara. (dengan Ibu Siin, S.PdWawancara: 16 Desember 2016).

Pendidikan PKn sebagai salah satu bagian dari pendidikan yang akan membentuk karakter anak bangsa menjadi anak bangsa yang peduli akan kehidupan selanjutnya juga yang mendukung tujuan pendidikan nasional, dimana tujuan pendidikan nasional itu bertujuan untuk mencerdaskan kehidupan bangsa dan memebentuk manusia seutuhnya yaitu manusia yang beriman dan bertakwa terhadap Tuhan Yang Maha Esa, berbudi luhur, berkepribadian mandiri serta memiliki rasa tanggung jawab yang tinggi terhadap kehidupan masyarakat dan bangsa.

Setelah mengaplikasikanya disekolah diharapkan juga bagi siswa kelas SMP Darul Hikmah Mataram mampu membiasakn diri untuk selalu solat barjamaah dirumah, selalu menjalankan puasa pada bulan romadhan tanpa ada paksaan. Dilaksanakan dengan penuh kesadaran. Karena mereka manyadari bahwa itu merupakan kebutuhan dan kewajiban yang harus dilak-sanakan dengan penuh keikhlasan untuk melaksanakan dan menerapkan kebisaaan-kebiasaan diatas dalam rangka mendidik siswa supaya menjadi insan yang bertakwa dan berakhlakul karimah. Maka sekolah khususnya guru BP memberikan sanksi atau hukuman kepada siswa yang tidak menjalankan kebiasaan-kebiasaan tersebut. Seperti doa bersama sebelum masuk kelas dilapangan, mengikuti kegiatan kultum, Al-Quran, berzanji lebih-lebih mengikuti sholat berjamaah di sekolah (Bapak Saharudin, S.Pdi Wawancara : 20 Desember 2016).

Hal yang hampir sama juga dipaparkan oleh apak H. Tri Handoko A.Md, namun yang bebrbeda adalah pernyataan tambahan berupa pentingnya melatih siswa-siswi untuk cinta lingkungan diawali dari lingkungan sekolah. Berikut pernyataannya;

Selain mengadakan lintas alam, SMP Darul Hikmah Mataram dalam menumbuhkan semangat nasionalisme yaitu rasa cinta tanah air dikalangan siswa, para siswa dilatih untuk mencintai sekolah dan lingkungan dengan melestarikan lingkungan yang ada disekitarnya dengan menanam bunga dan pohonpohon selain melestarikan lingkungan, para siswa juga mengadakan lintas alam supaya siswa memiliki wawasan luas tentang lingkungan alam yang ada disekitarnya (Wawancara,24 Desember 2016).

\section{TEMUAN DAN DISKUSI}

Pembelajaran PKn seperti apa yang telah dikatakan di atas, sarat dengan pelajaran berharga yang bersifat didaktis yaitu mendidik. Mendidik manusia supaya manusia itu bisa menemukan jati dirinya yang sesungguhnya. Karena pada dasarnya pendidikan baik pembelajaran PKn didalamnya mempunyai tujuan yaitu menumbuhkan dan mengembangkan keperibadian peserta didik, termasuk didalamnya pembentukan watak, sementara itu nilai-nilai pendidikan yang diajarkan dari materi PKn tidak lepas dari nilai-nilai budaya bangsa kita yang mengandung nilai-nilai luhur yang menjadi watak dam keperibadian bangsa kita, yang kesemuanya itu termaktub didalam falsafah bangsa kita yaitu Pancasila yang menjadi dasar dan pedoman Negara kita.

Para guru sebagai penggerak perubahan hendaknya memperkaya nilai-nilai moral dan norma pada siswadisekolah, baik mlalui kegiatan keagamaan, memberikan nasihat pada saat upacara bendera maupun kegiatan di kelas dengan menanamkan nilai-nilai yang terkandung pada materi yang diajarkan seperti pada pembelajaran PKn, diajarkan nilai-nilai apa yang terkandung dalam setiap materi PKn. Sehingga siswa menjadi termotivasi dan kesan yang timbul selama ini tentang pembelajaran PKn yang dianggap membosankan itu jadi hilang. Dengan semakin memperkaya nilai-nilai moral maka akan memberi pegangan hidup yang kokoh bagi siswa dalam menghadapi perubahan sosial. Kematangan secara moral akan menjadikan siswa mampu memperjelas dan menentukan sikap terhadap nilai dan norma baru yang muncul dalam proses perubahan. Hal tersebut sejalan dengan pendapat peran guru dalam meningkatkan sikap nasionalisme siswa melalui membimbing dan memberikan pesan-pesan moral pada siswa, memberikan nilai nasionalisme dengan menceritakan kisah-kisah para pahlawan dalam proses belajar mengajar, menggunakan metode yang bervariasi agar siswa tidak bosan dan cara tersebut dinilai efektif[10].

Sikap patriotisme merupakan suatu hal yang sangat perlu ditanamkan dalam jiwa peserta didik, karena sikap Patriotisme membentuk jiwa siswamenjadi tegar, kuat dan menjadi tahan banting terhadap rintangan terutama didalam belajar, lebih-lebih dalam mengarungi kehidupan sehari-hari yang penuh dengan tantangan dan rintangan. Dengan semangat patriotisme yang telah dicontohkan oleh para pendahulu bangsa, para siswajuga diajarkan untuk lebih mencintai tanah airnya, rela mengorbankan kepentingan pribadi demi kejayaan dan kemakmuran bangsa., apa lagi siswaitu mampu berkata seperti ungkapan Presiden pertama Republik Indonesia Bung Karno yang mengatakan " aku cinta jiwaku, tapi aku lebih cinta negaraku”. Sungguh ungkapan patriot sejati yang harus dicontoh dan diteladani.Apa lagi dengan mengingat kondisi bangsa kita yang saat ini sudah mulai mengarah pada disintegrasi bangsa, karena semakin lemahnya semangat persatuan dan kesatuan. Oleh karena itu semangat patriotisme perlu ditumbuhkan pada diri pesrta didik khususnya melalui pembelajaran PKn dikelas, dengan menyajikan hal-hal yang positif mengenai kebesaran bangsa dan kepahlawanan putera-puteri terbaik bangsa.

Nasionalisme dan patriotisme tidak hanya ditanamkan pada mata pelajaran dan perangkat 
pembelajaran melainkan pembinaan pada kegiatan formal dan non formal yang ada di sekolah[15].

Pembelajaran PKn yang dilaksanakan di kelas dalam upaya menanamkan sifat nasionalisme. Siswatidak hanya dilakukan didalam kelas saja tapi juga dilkukan diluar kelas. Pembelajaran yang dilakukan di dalam kelas hanya memberikan teori dan gambaran kepada siswatentang apa yang dibahas, tapi untuk memberikan pemahaman kepada siswadalam rangka meningkatkan daya kritisnya, maka siswadibawa belajar diluar kelas.

Kesetiaan pada bangsa dan tanah air, khususnya di SMP Darul Hikmah Mataram selalu dijaga pada diri peserta didik, sikap setia ini selalu ditanamkan baik dengan menggunakan tindakan maupun dengan menggunakan nasihat, sehingga mereka terbiasa melaksanakan kewajibannya dengan penuh kerelaan dan tanpa paksaan, sikap setia ini dapat kita lihat pada siswa, mereka sudah terbiasa melaksanakan upacara bendera setiap hari senin, bahkan dijadikan sebagai program osis, baik program jangka pendek maupun program jangka panjang, mereka dilatih hidup disiplin, ditanamkan rasa cinta pada budaya sendiri, dan yang lebih penting dari itu mereka dibina dan dilatih menjadi generasi yang setia pada tanah air melalui kegiatan-kegiatan keperamukaan, upacara bendera, dan terutama melalui pembelajaran PKn sebagai pembangkit kesadaran anak didik tentang karakter dan budaya bangsanya yang mengandung nilai-nilai luhur dan nilai moral.

Pembangunan di Indonesia dalam upaya mengisi kemerdekaan, terus menerus digalakkan dan dilaksanakan, baik dari zaman orde lama, orde baru, sampai zaman reformasi sekarang ini.Pembangunan itu sangat penting, tapi tidak kalah pentingnya sebelum mengadakan pembangunan membangun manusia yang melaksanakan pembangunan itu sendiri. Pembangunan itu tidak akan berhasil apabila manusianya tidak dibangun terlebih dahulu, mental spritualnya dibangun, kesadarannya ditingkatkan dan moralnya diperbaiki, sehingga tidak akan ada yang namanya sampah pembangunan. Membangun bukan hanya membangun fisik saja tapi juga mentalnya perlu dibangun, sehingga terwujud keadilan dan kemakmuran, karena pemerataan pembangunan, dan apa yang menjadi tujuan pembangunan nasional akan terwujud dan berhasil dilaksanakan yaitu membangun manusia Indonesia seutuhnya.

\section{E. SIMPULAN DAN SARAN}

Pembelajaran PKn pada masa sekarang ini sangat perlu sekali ditingkatkan, bukan hanya menyampaikan materi seperti apa yang ada dibuku, tapi yang lebih penting dari itu guru harus mampu menyampaikan nilai-nilai yang ada dalam setiap materi yang dipelajari, sehingga dengan demikian, pembelajaran PKn tidak dipandang sebelah mata dan tidak terkesan membosankan. Pembelajaran PKn yang diajarkan dikelas harus mampu menumbuhkan kesadaran siswatentang jati dirinya dan tanah airnya.

Adapun aspek-aspek nasionalisme yang harus dimiliki oleh siswaantara lain: Setia pada nusa bangsa, Sadar pada panggilan tugas, Toleransi satu sama lain. Semua aspek-aspek ini dimiliki oleh siswadi SMP Darul Hikmah Mataram berkat adanya penanaman kesadaran akan nilai-nilai PKn dan sikap-sikap lain yang mencerminkan sikap nasionalisme, seperti apa yang telah dicontohkan oleh generasi pendahulu bangsa, sehingga pembelajaran PKn di SMP Darul Hikmah Mataram memiliki peranan yang sangat penting karena mampu mendukung tumbuhnya sikap dan semangat nasionalisme seperti apa yang dilaksanakan oleh para siswa dalam kehidupan sehari-hari disekolah. Semua ini tidak lepas dari upaya guru PKn dan guru-guru yang lain dalam menanamkan nilai-nilaimoral dan kesadaran terutama semangat dan sikap nasionalisme yang mendorong perubahan pada diri peserta didik.

Dari hasil penelitian yang peneliti peroleh, maka disini peneliti bermaksud memberikan beberapa saran sebagai berikut:

a) Diharapkan bagi guru bidang studi PKn, hendaknya didalam memberikan materi pelajaran supaya memberikan penekanan tentang nilai-nilai apa yang terkandung didalamnya, sehingga siswamenjadi termotivasi dan semangat dalam mengikuti pelajaran.

b) Diharapkan bagi guru SMP Darul Hikmah Mataram khususnya guru PKn supaya menggunakan metode dan strategi mengajar yang merangsang minat siswa didalam belajar, tidak hanya didalam kelas saja, tapi diusahakan juga belajar diluar kelas.

c) Bagi pihak sekolah diharapkan supaya semakin meningkatkan kedisiplinan siswa yang telah ada, supaya para siswamenjadi generasi yang cakap dan bertanggung jawab, baik bagi diri, keluarga,masyarakat dan tanah airnya.

d) Diharakan juga bagi pihak sekolah, supaya semakin meningkatkan semangat nasionalisme siswa, baik melalui kegiatan-kegiatan ekstrakulikulermaupun melalui kegiatan-kegiatan yang mampu meningkatkan sumber daya manusia sehingga dapat mewujudkan tujuan pembangunan nasional, yaitu membentuk manusia Indonesia seutuhnya dan mampu mengisi kemerdekaan dengan pembangunan.

e) Kepada orang tua, selaku wali murid diharapkan supaya mampu memberikan motivasi dan semangat belajar bagi anak-anaknya, supaya menjadi anak yang cerdas, bertanggung jawab, dan mampu mewarisi sikap dan semangat para pendiri bangsa, terutama dalam kehidupan sehari-hari disekolah, masyarakat dan terutama sekali dalam kehidupan berbangsa dan bernegara. 
f) Bagi para pesera didik supaya lebih meningkatkan semangat belajarnya, meningkatkan ketekunan-nya, dan juga semakin meningkatkan kedisiplinannya, supaya mampu menjadi anak yang sukses, cerdas, dan bertanggung jawab.

g) Diharapkan juga bagi peneliti-peneliti selanjutnya, supaya hasil penelitian ini memberikan sumbangan yang berharga dalam menyesuaikan penelitian selanjutnya.

h) Penelitian lanjutan.

\section{UCAPAN TERIMA KASIH}

Penulis mengucapkan terima kasih kepada Pimpinan FKIP UM Mataram memberikan bimbingan, nasehat, dan motivasi kepada penulis sehingga penelitian ini dapat diselesaikan tepat waktu sesuai yang direncanakan.

\section{DAFTAR RUJUKAN}

[1] N. Fattah, "Manajemen Pendidikan," Jogjakarta: Ar-Ruzz Media, 2012.

[2] H. J. Muchtar, "Fikih Pendidikan," 2017.

[3] M. H. Affan, "Membangun Kembali sikap Nasionalisme Bangsa Indonesia dalam Menangkal Budaya Asing di Era Globalisasi," J. Pesona Dasar, vol. 3, no. 4, 2016.

[4] A. S. Fibrianto and S. Bakhri, "Pelaksanaan Aktivitas Ekstrakurikuler Paskibra (Pasukan Pengibar Bendera) Dalam Pembentukkan Karakter, Moral Dan Sikap Nasionalisme Siswa Sma Negeri 3 Surakarta," J. Moral Kemasyarakatan, vol. 2, no. 2, pp. 75-93, 2017.

[5] M. Z. Alfaqi, "Memahami Indonesia Melalui Prespektif Nasionalisme, Politik Identitas, Serta Solidaritas," J. Ilm. Pendidik. Pancasila dan Kewarganegaraan, vol. 28, no. 2, 2016.

[6] O. Darmayati, I. Suntoro, and H. Yanzi, "Pengaruh Budaya dan Lingkungan Sekolah Terhadap Sikap Nasionalisme Siswa," J. Kult. Demokr., vol. 3, no. 4, 2015.

[7] W. Hamisa, "Peranan Pembelajaran Pendidikan Kewarganegaraan dalam Menanamkan Sikap Nasionalisme Siswa di Era Globalisasi," Purwokerto Jur. Pendidik. Pancasila dan Kewarganegaraan, 2013.

[8] W. Wuryandani, "Integrasi nilai-nilai kearifan lokal dalam pembelajaran untuk menanamkan nasionalisme di sekolah dasar," in Proceding seminar nasional lembaga penelitian UNY, 2010, pp. 1-10.

[9] S. M. Suripto, "Pelaksanaan Ekstrakurikuler
Paskibra (Pasukan Pengibar Bendera) dalam Upaya Menumbuhkan Sikap Nasionalisme Siswa di SMP Negeri 3 Malang," J. HKN FIS $U M$, vol. 3, no. 6, 2015.

[10] R. A. Trisandi, "Peran Guru Sejarah Dalam Meningkatkan Sikap Nasionalisme Siswa Kelas XI IPS SMA Negeri 3 Slawi Tahun Ajaran 2012/2013." Universitas Negeri Semarang, 2013.

[11] L. J. Moleong, "Metodologi Penelitian Kualitatif,(Bandung: Remaja Rosdakarya, 2010), cet," Ke-13, $h$, vol. 111.

[12] Sugiyono, Metode Penelitian Pendidikan $R$ \& D. Bandung: Alfabeta, 2017.

[13] A. Suharsimi, "Prosedur Penelitian, Jakarta: PT," Rineka Cipta, p. 201:274, 2013.

[14] Sugiyono, Metode Penelitian Pendidikan:(Pendekatan Kuantitatif, Kualitatif dan $R \&$ \&). Alfabeta, 2014.

[15] I. RAWANTINA and N. Iriane, "Penanaman nilai nasionalisme dan patriotisme untuk mewujudkan pendidikan karakter pada mata pelajaran pendidikan kewarganegaraan siswa kelas x sma negeri 4 sidoarjo," Kaji. Moral dan Kewarganegaraan, vol. 1, no. 1, pp. 3954, 2013. 